\title{
Correction to: Geothermal Prospectivity of the Bigadic Basin and Surrounding Area, NW Anatolia, Turkey, by the Spectral Analysis of Magnetic Data
}

\author{
Funda Bilim, ${ }^{1}$ Attila Aydemir, ${ }^{2,3}$ and Abdullah Ates ${ }^{4}$
}

Correction to: Pure Appl. Geophys.

https://doi.org/10.1007/s00024-021-02787-y

In this article reference "Pourteau, A., Candan, O., \& Oberhansli, R. (2010). High pressure metasediments in central Turkey: Constraints on the Neotethyan closure history. Tectonics, 29, TC5004" was written incorrect by mistake and should have been "Ozdamar, S., Billor, M. Z., Sunal, G., Esenli, F., \& Roden, M. F. (2013). First U-Pb SHRIMP zircon and ${ }^{40} \mathrm{Ar} /{ }^{39} \mathrm{Ar}$ ages of metarhyolites from the
Afyon-Bolkardag Zone, SW Turkey: Implications for the rifting and closure of the Neo-Tethys. Gondwana Research, 24, 377-391". This has been corrected now.

Publisher's Note Springer Nature remains neutral with regard to jurisdictional claims in published maps and institutional affiliations.

The original article can be found online at https://doi.org/10.1007/ s00024-021-02787-y.

1 Geophysical Engineering Department, Engineering Faculty, Cumhuriyet University, 05480 Sivas, Turkey.

2 Yavuz Selim Mah., 548. Cad., Dogakent Camlik Sitesi, No: 11/12, Etimesgut, Ankara, Turkey. E-mail: attila.aydemir@gmail.com

3 Energy Systems Engineering Department, Engineering Faculty, Atılım University, Ankara, Turkey.

4 Geophysical Engineering Department, Engineering Faculty, Ankara University, 06100 Ankara, Turkey. 